\title{
Blackberry (Rubus spp.): influence of ripening and processing on levels of phenolic compounds and antioxidant activity of the 'Brazos' and 'Tupy' varieties grown in Brazil
}

\begin{abstract}
Amora Preta (Rubus spp.): influência do estádio de maturação e do processamento nos teores de compostos fenólicos e atividade antioxidante das variedades 'Brazos' e 'Tupy' cultivadas no Brasil
\end{abstract}

\author{
Acácio Antonio Ferreira Zielinski ${ }^{I^{*}}$ Caroline Goltz ${ }^{\mathrm{I}}$ Maira Akemi Casagrande Yamato \\ Suelen ÁvilaII Elisa Yoko Hirooka ${ }^{\text {III }}$ Gilvan WosiackiII Alessandro Nogueira ${ }^{I I}$ \\ Ivo Mottin Demiate ${ }^{I I}$
}

\begin{abstract}
Fruits from temperate and tropical climates which have high levels of antioxidant compounds are the source of numerous studies concerning the correlation with benefits to human health. The objectives of this study were to quantify the anthocyanins and phenolic compounds and also to measure the antioxidant activity (ferric reducing antioxidant power - FRAP) of blackberries from two varieties grown in southern Brazil ('Brazos' and 'Tupy') at three stages of ripening; unripe, semi-ripe, ripe and their products (pulp and fermented products). During fruit ripening it was observed that weight, size, diameter and sugars increase significantly and acidity decreased significantly. The anthocyanin content ranged from 4.19 (semi-ripe 'Tupy'variety) to 205.75mg $100 \mathrm{~g}^{-1}$ (ripe 'Brazos'variety). The highest levels of phenolic compounds were observed for the unripe fruit of both varieties, while antioxidant activity showed no significant difference during the ripening stages. The studied pulp showed a high content of phenolic compounds (ten times higher than that found in the ripe fruits). The anthocyanin content and antioxidant activity did not show the same increase due to the degradation of anthocyanins caused by the heat treatment that was used. The alcoholic fermented beverage made from blackberries remained stable (total phenolic compounds and antioxidant activity) during two years of storage, but the in third year a significant reduction in antioxidant activity was observed. These results can be important for establishing the shelf life of this kind of product made with blackberry.
\end{abstract}

Key words: Rubus spp., antioxidant activity, ripening stage, processing.

\section{RESUMO}

Algumas frutas de clima temperado e tropical, principalmente as do tipo "berries", têm como característica o acúmulo de compostos antioxidantes e são objeto de inúmeros estudos, haja vista a sua correlação com os beneficios para a saúde humana. Os objetivos deste trabalho foram quantificar as antocianinas, os compostos fenólicos e mensurar a capacidade antioxidante (ferric reducing antioxidant power - FRAP) de amoraspretas de duas cultivares ('Brazos'e 'Tupy'), nos três estágios de maturação, considerados verde, semi-maduro e maduro, e dos seus produtos (polpas e fermentados). No processo de maturação da fruta, observou-se que o peso, tamanho, diâmetro e teor de açúcar aumentaram significativamente enquanto a acidez diminuiu. Os teores de antocianinas aumentaram de 4,19 (FSM cv. 'Tupy') (frutos semimaduros) para 205,75mg $100 \mathrm{~g}^{-1}$ (FM cv. 'Brazos') (frutos maduros). Os maiores teores de compostos fenólicos foram verificados para os frutos verdes (FV) das duas cultivares, enquanto a atividade antioxidante não apresentou diferença significativa nos estádios de maturação. A polpa estudada acumulou um elevado teor de compostos fenólicos (dez vezes superior ao encontrado nas frutas maduras). Os teores de antocianinas e de atividade antioxidante não apresentaram o mesmo perfil em função da degradação das antocianinas pelo processo térmico utilizado. O fermentado alcoólico de amora permaneceu estável (fenóis totais e atividade antioxidante) durante dois anos de estocagem, porém, no terceiro ano, foi observada uma redução significativa da atividade antioxidante. Estes resultados são importantes para o estabelecimento da vida-de-prateleira desses produtos derivados da amora.

Palavras-chave: Rubus spp., atividade antioxidante, estádio de maturação, processamento.

\section{INTRODUCTION}

Due to the fact that it is a very rustic plant and easy to handle, the cultivation of blackberries

'Programa de Pós-graduação em Engenharia de Alimentos (PPGEAL), Universidade Federal do Paraná (UFPR), Rua XV de Novembro, 1299, 80060-000, Curitiba, PR, Brasil. E-mail: aczielinski@gmail.com. *Corresponding author.

"Programa de Pós-graduação em Ciência e Tecnologia de Alimentos (PPGCTA), Universidade Estadual de Ponta Grossa (UEPG), Ponta Grossa, PR, Brasil.

"IIPrograma de Pós-graduação em Ciência de Alimentos (PPGCA), Universidade Estadual de Londrina (UEL), Londrina, PR, Brasil. Received 08.21.12 Approved 04.07.14 Returned by the author 12.14.14 CR-2012-0715.R6 
(Rubus spp.) is a promising alternative source of income for small family farms in Brazil (CLERICI \& CARVALHO-FILHO, 2011; FERREIRA et al., 2010; HIRSCH et al., 2012). The blackberry is a small fruit and it is characterized by being labor-intensive and also for the possibility of providing a high economic return. Small fruits are recognized, both in the literature and in everyday life, as beneficial to human health with properties linked with the prevention of disease and the remission of symptoms. Scientific papers have been widely publicized and have encouraged the creation of a special group of fruits, still in the process of definition, but with the name of "superfruits" (HASSIMOTTO et al., 2008; ACOSTA-MONTOYA et al., 2010; VIZZOTTO et al., 2012).

Among these small red fruits the blackberry shows some of the highest levels of anthocyanins closely following the black raspberry and superior to the strawberry (WANG \& LIN, 2000; ACOSTAMONTOYA et al., 2010). These flavonoids are considered to be primarily responsible for antioxidant activity, which explains the functionality of the fruits in general, and more specifically, that of the blackberry. The pigments responsible for their typical color (anthocyanins) are already well known and studied as potential antioxidants that provide benefits to the human health. Anthocyanins are hydrophilic pigments that give the various shades of orange, red and blue there are present in fruits, vegetables, leaves, flowers and roots, due to reversible structural changes of the flavylium cation, which is sensitive to $\mathrm{pH}$ changes intrinsic to plants (MOTA, 2006). The main anthocyanic compounds in blackberries, associated with antioxidant activity, are the anthocyanins, cyanidin-3-glucoside and cyanidin-3-(6"-malonyl) glucoside; as well as ellagitannins, lambertianin sanguiin C; and H-6 complex (ACOSTA-MONTOYA et al., 2010).

Although there are native species of the Rubus genus in Brazil, the blackberry only started to be studied in the 1970s, and the first varieties introduced to the country were the 'Brazos', 'Comanche' and 'Cherokee', all from the United States, the world's largest producer. After a genetic program conducted by the Brazilian Agricultural Research Company (EMBRAPA), new Brazilian varieties came into the market, including 'Tupy', launched in the late 1980 s, which is now the main variety produced in the country (ANTUNES, 2002). There is still only little technical and scientific information regarding the use of the blackberry as raw material for adding value to agricultural produce that has begun to emerge in southern Brazil in a promising manner. So, this study seeks to identify the effects of processing on the quality of products made from different varieties of blackberries. Considering the lack of scientific data on blackberries cultivated in Brazil, the objective was to quantify the total phenolic compounds and total monomeric anthocyanins. It was also intended to measure the antioxidant activity of the 'Brazos' and 'Tupy' varieties in three stages of ripeness (unripe, semi-ripe and ripe) and of the pulp from ripe fruits from the 2009 harvest, and also from alcoholic fermented products from 2007, 2008 and 2009.

\section{MATERIALS AND METHODS}

The blackberry fruits ('Brazos' and 'Tupy' varieties) harvested in 2009, alcoholic fermented blackberries (from 2007, 2008 and 2009 harvests) and blackberry pulp were kindly provided by Adega Porto Brazos (Ponta Grossa, PR, Brazil). The fruits were harvested unripe ( $>75 \%$ of the skin green), semiripe ( $>75 \%$ with red skin), and ripe $(100 \%$ of the skin dark purple). In the case of the alcoholic fermented blackberries ('Brazos' variety), their production involved juice extraction from ripe fruits by using a horizontal de-pulper (D-008, Mecamau, Espirito Santo do Pinhal, São Paulo, Brazil), sugar addition to $22.5^{\circ}$ Brix and inoculation with $10^{6}$ cells $\mathrm{mL}^{-1}$ of Saccharomyces cerevisiae Fermol Bouquet (AEB Group, São José dos Pinhais, Paraná, Brazil). The alcoholic fermentation started in open tanks, with intercalated addition of sugar (commercial sucrose). After the tumultuous phase, the fermentation was racked into $10 \mathrm{~m}^{3}$ tanks (JAPA Components, Garibaldi, Rio Grande do Sul, Brazil) which were closed with a bung for 30 days. After that, the product was filtrated ( $10 \mu \mathrm{m}$, Hidro filtros of Brazil, Caxias do Sul, Rio Grande do Sul, Brazil) and stored without preservative in a $10 \mathrm{~m}^{3}$ bulk fermenter at $20^{\circ} \mathrm{C}$. The analyses were carried out at the beginning of 2010 for all the samples. At that time, the fermented product from 2009 had just concluded fermentation whereas the others had been stored for one and two years. The blackberry pulp (marketed by the producer) consisted of the solid residue obtained from the de-pulping processing. The pulp was pasteurized (two hours at boiling temperature at $97^{\circ} \mathrm{C}$ ), cooled and packaged (low density polyethylene) being stored frozen $\left(-18^{\circ} \mathrm{C}\right)$.

Extraction of anthocyanins from fruit and pulp: The fruit and pulp (separately) were macerated in mortar and the soluble fractions were extracted by vacuum filtration with a mixture of acidified methanol (99:1, MeOH: $\mathrm{HCl}$ conc.) with Whatman paper no2 
in a Büchner funnel. The extract was concentrated using a rotary evaporator (Tecnal TE-211, Piracicaba $\mathrm{SP}$, Brazil) at low temperature $\left(40^{\circ} \mathrm{C}\right)$ up to $10 \%$ of the initial volume, filtered through a $0.45 \mu \mathrm{m}$ PVDF membrane (Millipore) and stored in an amber bottle at $4.0 \pm 1.0^{\circ} \mathrm{C}$ (LEES \& FRANCIS, 1972).

Extraction of total phenolic compounds from fruit and pulp: The fruit and pulp (separately) were macerated in mortar and the soluble fractions were extracted by vacuum filtration using a mixture of $80: 20: 1,70^{\circ}$ ethanol: distilled water: $3 \%$ formic acid (ZARDO et al., 2009).

Physicochemical analysis: The weight and size (length and width) of the fruit were determined by measuring an individual number of each sample. The weight was determined using a digital scale AX200 model (SHIMADZU) and the overall length and width with a caliper (INSIZE). The dry extract, mineral residue (ash), acidity and dietary fiber were determined using the methods of IAL(2008). Reducing sugars were determined according NELSON (1944) and SOMOGYI (1945) and glucose was determined by the enzymatic method using a glucose oxidase kit (Gold Analisa, Belo Horizonte MG, Brazil) with D-glucose as standard (DAHLQVIST, 1961). Fructose was indirectly estimated by performing a subtraction of the levels of the reducing sugars from glucose. The total phenolic compounds of phenolic extracts and fermentation were quantified by the Folin-Ciocalteu reagent using catechin as standard (SINGLETON \& ROSSI, 1965) and results were expressed in $\mathrm{mg} 100 \mathrm{~g}^{-1}$. Quantification of total monomer anthocyanins, anthocyanin extracts and fermentations was carried out using the differential
pH method (GIUSTI \& WORSLTAD, 2001) and results were expressed in mg of cyanidin 3-glucoside $100 \mathrm{~g}^{-1}$ fruit. For the analysis of antioxidant activity, the phenolic extracts and fermentations were measured by FRAP methodology as described by BENZIE \& STRAIN (1996) with modifications. The results were expressed as $\mu \mathrm{M}$ of total equivalent capacity (TEAC) per $g$ of sample.

Statistical analysis: The results of the experimental procedures were analyzed using analysis of variance (ANOVA), with 95\% reliability and if there were differences these were distinguished by Tukey's differential test at $5 \%$ probability using the statistical software STATISTICA 7.0 for Windows (Statsoft, Inc., São Caetano do Sul, São Paulo, Brazil).

\section{RESULTS AND DISCUSSION}

During the ripening the physical and chemical characteristics for both blackberries varieties were evaluated. Characteristics in relation to weight, size and diameter showed a significant increase with the evolution of ripening (Table 1). The parameters related to dry matter and mineral content showed a significant decrease in relation to unripe fruit compared to semi-ripe and ripe fruit. The levels of fibers decreased significantly during the maturation period. This occurs due to increased synthesis of endogenous enzymes during ripening which makes the fruit with soft texture. The sugar contents (Table 1) confirm the ripening stages (ACOSTAMONTOYA et al., 2010). The levels of glucose and fructose increased significantly during the period. The fruits of both 'Brazos' and 'Tupy' varieties showed a

Table 1 - Physical and chemical properties of blackberries at three different stages of maturation.

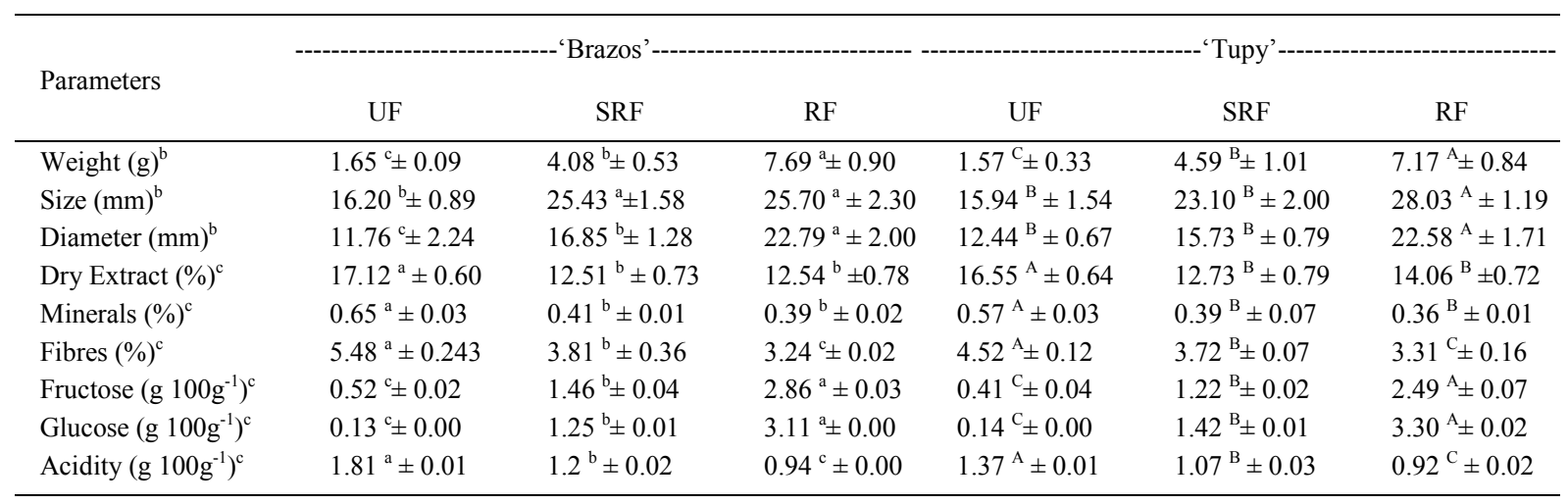

Note:

${ }^{a}$ Means \pm standard deviation. Values in the same row with similar letters are not significantly different (Tukey's test, $\mathrm{P}<0.05$ ). Lower case letters refer to 'Brazos' variety and uppercase refer to the 'Tupy' variety. UF = unripe fruit; SRF $=$ semi-ripe fruit; RF $=$ ripe fruit.

${ }^{\mathrm{b}} \mathrm{n}=60$.

${ }^{\mathrm{c}} \mathrm{n}=3$.

Ciência Rural, v.45, n.4, abr, 2015. 
decrease in the levels of acidity during the ripening period, as expected, making the fruits tasty and ready to be consumed or processed. Similar results were described for tropical highland blackberry (Rubus adenotrichus Schltdl.) by ACOSTA-MONTOYA et al. (2010). The physical results and sugar and acidity contents changed significantly during the blackberry ripening stage (Table 1).

The highest levels of total monomeric anthocyanins (TMA) were found in the ripe fruit (RF) (205.75mg 100 $\mathrm{g}^{-1}$ 'Brazos' and $168.53 \mathrm{mg} \mathrm{100g}^{-1}$ 'Tupy' (Table 2). When assessing the levels of anthocyanins for 'Brazos' and 'Tupy', HASSIMOTTO et al. (2008) determined values below those found in this study $\left(133.0 \mathrm{mg}^{100 \mathrm{~g}^{-1}}\right.$ and $116.0 \mathrm{mg}^{100 \mathrm{~g}^{-1}}$ ) and FERREIRA et al. (2010) found $104.1 \mathrm{mg}^{100 \mathrm{~g}^{-1}}$ for the 'Tupy' variety. The values found in the present study were within those presented by KOCA \& KARADENIZ (2009) for ten different blackberries

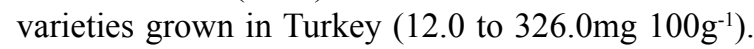
Other results similar to the levels of anthocyanins have also been reported by other authors (WANG \& LIN, 2000; SIRIWOHARN et al., 2004). Considering the maximum sensory acceptability of ripe fruits due to their high contents of sugars, low acidity, soft texture and color due high anthocyanins content and the importance of these compounds for human health principally as antioxidants, the results of the present study confirm that this is the preferred stage for fruit consumption as well as for its use as raw material for processing. The results show that functional molecules (anthocyanins and total phenolic compounds) as well as the antioxidant capacity are not decreased as blackberry fruits become ripe.

The levels of total phenolic compounds (TPC) decreased with the advancement of ripening and were determined in a higher concentration for unripe fruit of both varieties. In the 'Tupy' variety, semi-ripe fruits did not differ significantly from ripe fruits, while in the 'Brazos' variety it was observed that between these two stages the highest level was for ripe fruit. As reported by ACOSTA-MONTOYA et al. (2010), the main phenolic compounds determined of blackberries were ellagitannins (lambertianin $\mathrm{C}$ and sanguiin H-6) and anthocyanins (cyanindin-3glucoside and cyanidin-3-(6'-malonyl) glucoside), and in the semi-ripe fruit ellagitannins accounted for more than $92 \%$ of phenolic compounds and 61 $\%$ in ripe fruit. Ellagitannins, also referred to as hydrolysable tannins or ellagic acid derivatives (LEE et al., 2012) which are identified as active principles in traditional Chinese medicines (QUIDEAU, 2009) and are major phenolic compounds. These compounds are certainly associated with the antioxidant activity (SIRIWOHARN et al., 2004; ACOSTA-MONTOYA et al., 2010). Although they decrease during ripening of the blackberries, anthocyanins increase with the degree of maturity, as was observed for the 'Brazos' and 'Tupy'varieties.

The antioxidant activity determined by FRAP for the 'Brazos' variety did not present significant difference between the different stages

Table 2 - Results of total monomeric anthocyanins (TMA), total phenolic compounds (TPC) and antioxidant activity (FRAP) of blackberries at different stages of maturity.

\begin{tabular}{|c|c|c|c|}
\hline Samples & TMA (mg $\left.100 \mathrm{~g}^{-1}\right)$ & TPC (mg $\left.100 \mathrm{~g}^{-1}\right)$ & $\operatorname{FRAP}\left(\mu \mathrm{M} \mathrm{g}^{-1}\right)$ \\
\hline $\mathrm{RF}$ & $205.75^{\mathrm{a}} \pm 2.05$ & $169.41^{b} \pm 9.72$ & $33.85^{a} \pm 2.47$ \\
\hline SFR & $5.68^{b} \pm 0.71$ & $68.04^{c} \pm 3.45$ & $33.83^{\mathrm{a}} \pm 3.12$ \\
\hline UF & $\mathrm{Nd}$ & $185.84^{\mathrm{a}} \pm 0.79$ & $38.92^{\mathrm{a}} \pm 2.20$ \\
\hline $\mathrm{RF}$ & $168.53 \mathrm{a} \pm 2.74$ & $101.83 b \pm 9.32$ & $37.77 \mathrm{a} \pm 5.43$ \\
\hline SRF & $4.19 \mathrm{~b} \pm 0.93$ & $106.85 b \pm 7.25$ & $25.69 \mathrm{~b} \pm 5.47$ \\
\hline UF & $\mathrm{Nd}$ & $187.67 \mathrm{a} \pm 14.24$ & $33.93 \mathrm{a} \pm 2.20$ \\
\hline 'Brazos’ pulp & $94.55^{\mathrm{B}} \pm 1.53$ & $878.08^{\mathrm{B}} \pm 4.75$ & $64.63^{\mathrm{A}} \pm 3.08$ \\
\hline ‘Tupy’ pulp & $101.63^{\mathrm{A}} \pm 0.07$ & $1198.63^{\mathrm{A}} \pm 34.25$ & $46.28^{\mathrm{B}} \pm 0.68$ \\
\hline Fermented 2007 & $0.44^{\mathrm{D}} \pm 0.03$ & $312.79^{\mathrm{D}} \pm 19.87$ & $12.65^{\mathrm{D}} \pm 1.27$ \\
\hline Fermented 2008 & $2.27^{\mathrm{D}} \pm 0.07$ & $478.54^{\mathrm{C}} \pm 40.23$ & $44.43^{B} \pm 4.06$ \\
\hline Fermented 2009 & $5.23^{\mathrm{C}} \pm 0.13$ & $459.36^{\mathrm{C}} \pm 9.91$ & $36.15^{\mathrm{C}} \pm 3.78$ \\
\hline
\end{tabular}

Note: RF: ripe fruit; SRF: semi-ripe fruit; UF: unripe fruit.; nd: not determined. Means \pm standard deviation. Values in the same row with similar letters are not significantly different (Tukey's test $\mathrm{P}<0.05$ ). Lower case letters refer to blackberry fruits, and uppercase refer to blackberry product. 
of maturation. For the 'Tupy' variety the unripe and ripe fruits were those with the highest values. The antioxidant activities of the ripe fruits of both varieties were similar to those presented by KOCA \& KARADENIZ (2009) for ten different varieties of blackberries at a ripe stage of maturity (35.05 to $\left.70.41 \mu \mathrm{mol} \mathrm{g}^{-1}\right)$. As found in the present paper, VIZZOTTO et al. (2012) also reported a lack of correlation between total phenolic compounds and antioxidant activity in blackberries, although in many papers considering different vegetables a positive correlation exists. GORDON et al. (2012) reported decreasing antioxidant activity in açai fruits (Euterpe oleraceae Mart) during ripening, as did PINELI et al. (2011) when considering different ripening stages of strawberries. ACOSTA-MONTOYA et al. (2010) reported high values of antioxidant activity of unripe blackberry fruits and related this fact to non-anthocyanin phenolic compounds such as ellagitannins (Table 2). The results of the present research did not show decrease in the antioxidant activity during fruit ripening and that is the most important characteristic for the consumer.

The highest levels of anthocyanins were found among the blackberry pulp ('Brazos' and 'Tupy' varieties) and the 'Tupy' variety had the highest content $\left(101.63 \mathrm{mg} 100 \mathrm{~mL}^{-1}\right)$. The levels of total phenolic compounds and antioxidant activity were high for the pulp. The 'Tupy' variety presented the highest content of phenolic compounds $(1198.63 \mathrm{mg}$ $100 \mathrm{~mL}^{-1}$ ) and the 'Brazos' variety produced the

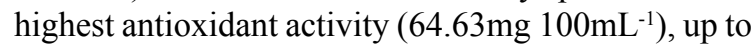
eleven times and twice as much as the concentration in fruit, respectively (Table 2). The high values of phenolic compounds can be due to the concentration by thermal process. The anthocyanins did not increase with this operation and this could be due to their instability at high temperatures (SHAHIDI \& NACZK, 1995).

It was observed that in the fermented products of the berries there was a decrease in the levels of anthocyanins during the storage period; the fermented berries with the greatest storage period had the lowest anthocyanin content across all the products (0.44mg $100 \mathrm{~mL}^{-1}$ ) (Table 2). PÉREZ-MAGARIÑO $\&$ JOSÉ (2004) evaluated the evolution of flavonoids and anthocyanins during the ageing of wines and found a decrease in free anthocyanins and flavonoids and an increase in anthocyanin derivatives that were responsible for maintaining the intensity of color in the aged wines. These reactions not only modify wine color but also bring about changes in such other attributes as astringency and bitter flavors. Fermented blackberries have a superior phenolic content when compared to that found in other fruit, possibly due to phenolic extraction by ethanol and carbon dioxide release in the initial stages of alcoholic fermentation. However, the free anthocyanin content reduces during processing and storage losing the function quality. This anthocyanin decrease is due to degradation reactions and sedimentation during long periods of storage (MARKAKIS, 1982). In the present study, antioxidant activity was similar to that found in fruits during the first two years of storage, but in the third year the decrease was greater than $50 \%$ (Table 2).

\section{CONCLUSION}

Blackberry pulp had the high levels of phenolic compounds and highest antioxidant activity, what should be related with its production method involving juice extraction in a depulper that concentrates fiber and other solids. The fermented beverages indicated the instability of anthocyanins with long storage period (loss of $92 \%$ in three years) and that antioxidant activity was stable for two years but there was a significant loss during the third year of storage $(>50 \%)$.

\section{ACKNOWLEDGEMENTS}

The authors are deeply grateful to Universidade Estadual de Ponta Grossa (UEPG), Coordenação de Aperfeiçoamento de Pessoal de Nível Superior (CAPES) and Conselho Nacional de Desenvolvimento Científico e Tecnológico $(\mathrm{CNPq})$ for the infrastructure and the scholarships offered in the implementation period of this research and also to Adega Porto Brazos for the supply of fruits and products.

\section{REFERENCES}

ACOSTA-MONTOYA, Ó. et al. Phenolic contend and antioxidant capacity of tropical highland blackberry (Rubus adenotrichus Schtdl.) during three edible maturity stages. Food Chemistry, v.119, p.1497-1501, 2010. Available from: <http://dx.doi. org/10.1016/j.foodchem.2009.09.032>. Accessed: Aug. 20, 2012. doi: 10.1016/j.foodchem.2009.09.032.

ANTUNES, L.E.C. Amora-preta: nova opção de cultivo no Brasil. Ciência Rural, v.32, n.1, p.151-158, 2002. Available from: $<$ http:// dx.doi.org/10.1590/S0103-84782002000100026>. Accessed: Aug. 20, 2012. doi: 10.1590/S0103-84782002000100026.

BENZIE, I.F.F.; STRAIN, J.J. The ferric reducing ability of plasma (FRAP) as a measure of "antioxidant power": the FRAP assay. Analytical Biochemistry, v.239, n.1, p.70-76, 1996. Available from: $\quad<$ http://dx.doi.org/10.1006/abio.1996.0292>. Accessed: Aug. 20, 2012. doi: 10.1006/abio.1996.0292.

CLERICI, M.T.P.S.; CARVALHO-SILVA, L.B. Nutritional bioactive compounds and technological aspects of minor fruits grown in Brazil. Food Research International, v.44, n.7, 
p.1658-1670, 2011. Available from: <http://dx.doi.org/10.1016/j. foodres.2011.04.020>. Accessed: Jan. 11, 2011. doi: 10.1016/j. foodres.2011.04.020.

DAHLQVIST, A. Determination of maltase and isomaltase activities with a glucose-oxidase reagent. Biochemical Journal, v.80, p.547-551, 1961.

FERREIRA, D.S. et al. Compostos bioativos presentes em amorapreta (Rubus spp.). Revista Brasileira de Fruticultura, v.32, n.3, p.664-674, 2010. Available from: <http://dx.doi.org/ http://dx.doi. org/10.1590/S0100-294520110005000110>. Accessed: Jan. 11, 2013. doi: 10.1590/S0100-294520110005000110.

GIUSTI, M.M.; WORSLTAD, R.E. Characterization and measurement of anthocyanins by UV-visible spectroscopy. Curr. In: WROLSTAD, R.E. Protocols in Food Analytical Chemistry. New York: Wiley, 2001.

GORDON, A. et al. Chemical characterization and evaluation of antioxidant properties of Açaí fruits (Euterpe oleraceae Mart.) during ripening. Food Chemistry, v.133, n.2, p.256263, 2012. Available from: <http://dx.doi.org/10.1016/j. foodchem.2011.11.150>. Accessed: Jan. 11, 2013. doi: 10.1016/j. foodchem.2011.11.150

HASSIMOTTO, N.M.A. et al. Physico-chemical characterization and bioactive compounds of blackberry fruits (Rubus sp.) grown in Brazil. Ciência e Tecnologia de Alimentos, v.28, n.3; p.702708, 2008. Available from: < http://dx.doi.org/10.1590/S010120612008000300029>. Accessed: Aug. 20, 2012. doi: 10.1590/ S0101-20612008000300029.

HIRSCH, G.E. et al. Caracterização físico-química de variedades de amora-preta da região sul do Brasil. Ciência Rural, v.42, n.5, p.942-947, 2012. Available from: <http://dx.doi.org/10.1590/ S0103-847820120050000021>. Accessed: Jan. 11, 2013. doi: $10.1590 / \mathrm{S} 0103-847820120050000021$

IAL. Métodos físicos e químicos para análise de alimentos. Normas Analíticas. São Paulo: Instituto Adolfo Lutz, 2008. Total de extrato seco, minerias, acidez e fibra dietética.

LEE, J. et al. Rubus fruit phenolic research: The good, the bad, and the confusing. Food Chemistry, v.130, n.4, p.785-796, 2012 Available from: $<$ http://dx.doi.org/10.1016/j.foodchem.2011.08.022>. Accessed: Apr. 30, 2013. doi: 10.1016/j.foodchem.2011.08.022.

LEES, D.H.; FRANCIS, F.G. Standardization of pigment analysis in cranberries. Hortscience, v.7, p.83-84, 1972.

KOCA, I.; KARADENIZ, B. Antioxidant properties of blackberry and blueberry fruits grown in the Black Sea Region of Turkey. Scientia Horticulturae, v.121, n.4, p.447-450, 2009. Available from: <http://dx.doi.org/10.1016/j.scienta.2009.03.015>. Accessed: Aug. 20, 2012. doi: 10.1016/j.scienta.2009.03.015.

MARKAKIS, P. Stability of anthocyanins in foods. In: MARKAKIS, P. Anthocyanins as food colors. New York: Academic, 1982. p.163-180.

MOTA, R.V. Caracterização do suco de amora-preta elaborado em extrator caseiro. Ciência e Tecnologia de Alimentos, v.26, n.2, p.303-308, 2006. Available from: <http://dx.doi.org/10.1590/ S0101-20612006000200012>. Accessed: Aug. 20, 2012. doi: $10.1590 / \mathrm{S} 0101-20612006000200012$.

NELSON, N. A photometric adaptation of the Somogyi method for the determination of glucose. Journal of Biological Chemistry, v.153, p.375-380, 1944.

PÉREZ-MAGARIÑO, S.; JOSÉ, M.L.G. Evolution of flavanols, anthocyanins, and their derivatives during the aging of red wines elaborated from grapes harvested at different stages of ripening. Journal of Agricultural and Food Chemistry, v.52, p.1181-1189, 2004. Available from: <http://dx.doi.org/10.1021/jf035099i > Accessed: Aug. 20, 2012. doi: 10.1021/jf035099i.

PINELI, L.L.O. et al. Antioxidants and other chemical and physical characteristics of two strawberry cultivars at different ripeness stages. Journal of Food Composition and Analysis, v.24, p.11-16, 2011. Available from: $<$ http://dx.doi.org/10.1016/j. jfca.2010.05.004>. Accessed: Jan. 11, 2013. doi: 10.1016/j. jfca.2010.05.004.

QUIDEAU, S. Chemistry and biology of ellagitannins: an underestimated class of bioactive plant polyphenols. Singapore: World Scientific Publishing, 2009. 374p.

SHAHIDI, F.; NACZK, M. Food phenolics: sources, chemistry, effects and applications. Lancaster: Technomic, 1995. 331p.

SINGLETON, V.; ROSSI, J.A. Colorimetry of total phenolics with phosphomolybdic- phosphotungstic acid reagents. American Journal of Enology and Viticulture, v.16, n.3, p.144-158, 1965.

SIRIWOHARN, T. et al. Influence of cultivar, maturity, and sampling on blackberry (Rubus L. hybrids) anthocyanins, polyphenolics, and antioxidant properties. Journal of Agricultural and Food Chemistry, v.52, n.26, p.8021-8030, 2004. Available from: <http://dx.doi.org/10.1021/jf048619y>. Accessed: Aug. 20, 2012. doi: $10.1021 / \mathrm{jf0} 48619 \mathrm{y}$.

SOMOGYI, M. A new reagent for the determination of sugars. Journal of Biological Chemistry, v.160, n.1, p.61-68, 1945.

VIZZOTTO, M. et al. Teor de compostos fenólicos e atividade antioxidante em diferentes genótipos de amoreira-preta (Rubus sp.). Revista Brasileira de Fruticultura, v.34, n.3, p.853858, 2012. Available from: <http://dx.doi.org/10.1590/S010029452012000300027>. Accessed: Jan. 11, 2013. doi: 10.1590/ S0100-29452012000300027.

WANG, S.Y.; LIN, H.S. Antioxidant activity in fruits and leaves of blackberry, raspberry, and strawberry varies with cultivar and developmental stage. Journal of Agricultural and Food Chemistry, v.48, p.140-146, 2000. Available from: <http://dx.doi. org/10.1021/jf9908345>. Accessed: Aug. 20, 2012. doi: 10.1021/ jf9908345.

ZARDO, D.M. et al. Intensidade de pigmentação vermelha em maçãs e sua relação com os teores de compostos fenólicos e capacidade antioxidativa. Ciência e Tecnologia de Alimentos, v.29, n.1, p.148-154, 2009. Available from: <http://dx.doi. org/10.1590/S0101-20612009000100023>. Acessed: Jan. 11, 2013. doi: 10.1590/S0101-20612009000100023. 